DOI: doi.org/10.21272/shaj.2021.i36.p.15

\author{
VIACHESLAV O. OLITSKYI \\ $\mathrm{PhD}$ (History), Sumy State Pedagogical University named after A.S. Makarenko (Ukraine)
}

\title{
COVERAGE OF THE PRIMARY EDUCATION DEVELOPMENT IN 1941-1943 BY LOCAL PRESS OF THE MILITARY COMMAND ZONE
}

\begin{abstract}
The aim of the study is to reveal the coverage of forming and developing of primary education in the zone of military command by the local press. The methodology is based on the use of general scientific and special-historical research methods, including problem and chronological, comparative-historical, typological, etc. Scientific novelty. For the first time in modern Ukrainian historiography, the local press of the military command zone of the Nazi occupation period became the object of study with the focus on primary education. The classification of local press publications on establishing and developing primary education in the military command zone was proposed. Conclusions. Materials of the local press are an important source for researching the restoration and development of primary education in the zone of military command. Functioning the local newspapers was due to the support of the occupying power, the press was seen as one of the elements of propaganda. This affected the content of peridicals and the way of presenting information. Due to a number of reasons, including low circulation and delivery problems, propaganda through local periodicals had certain effect only in some regions. A number of newspaper publications revealed the peculiarities of everyday life in the occupied territories, including the re-establishiment and development of primary education. Such materials can be divided into several groups: coverage of organizing and features of the educational process; statistical data, didactic materials; characteristics of pedagogical staff and their professional development. They were the least exposed to propaganda, their authors were mostly members of local authorities. Publications on primary education concerned the administrative units where newspapers were published, and they did not contain general materials. Some of the publications dealt with specific tasks related to restoring and developing educational institutions, the educational process and the results of their implementation. There is a significant segment of material of the critical nature, mainly in relation to teachers: their appearance, behavior, teaching methods. Such notes were mostly impersonal, while praising information was always personal. Articles on the educational process were more influenced by propaganda and were placed on the front pages.
\end{abstract}

Keywords: World War II, military command zone, primary education, occupation, press, propaganda.

Citation. Olitskyi V.O. Coverage of the primary education development in 1941-1943 by local press of the Military Command Zone. Sumskyi istoryko-arkhivnyy zhurnal [Sumy historical and archival journal]. №XXXVI. 2021. Pp. 15-26. DOI: doi.org/10.21272/shaj.2021.i36.p.15

ОЛІЦьКИЙ в.о.

Кандидат історичних наук, Сумський державний педагогічний університет імені А.С. Макаренка (Україна)

\section{ВИСВІТЛЕННЯ РОЗВИТКУ ПОЧАТКОВОЇ ОСВІТИ У 1941-1943 РР. МІСЦЕВОЮ ПРЕСОЮ ЗОНИ ВІЙСЬКОВОГО КОМАНДУВАННЯ}

Анотація. Мета дослідження полягає у розкритті висвітлення місцевою пресою становлення та розвитку початкової освіти у зоні військового командування. Методологія грунтується на використанні загальнонаукових і спеціально-історичних методів дослідження, у тому числі проблемно-хронологічного, порівняльно-історичного, типологічного та ін. Наукова новизна. Уперше у сучасній украӥнській історіографї̈ місиева 
преса зони військового командування періоду нацистської окупаџї стала об'єктом вивчення через призму розвитку початкової освіти. Запропоновано класифікацію публікацій місцевої преси стосовно становлення та розвитку початкової освіти у зоні військового командування. Висновки. Матеріали місиевої преси є важливим джерелом вивчення відновлення та розвитку початкової освіти в зоні військового командування. Функиіонування місцевих газет відбувалося завдяки підтримці окупаційної влади, преса розглядалася як один із елементів пропаганди. Це впливало на інформаційне наповнення часописів та спосіб подачі інформації. У зв'язку із рядом причин, у тому числі малими тиражами та проблемами доставки, пропаганда засобами місиевої періодики мала певний ефект лише в окремих районах. Ряд газетних публікацій розкривали особливості повсякденного життя на окупованій території, у тому числі питання відновлення та розвитку початкової освіти. Такі матеріали умовно можна поділити на кілька груп: висвітлення організації та особливостей навчального прочесу; статистичні дані; дидактичні матеріали; характеристика педагогічних кадрів та підвищення їх кваліфікації. Вони найменше піддавалися пропаганді, їх авторами були переважно члени місцевих управ, які безпосередньо займалися галуззю освіти. Публікачї присвячені початковій освіті стосувалися адміністративних одиниць на яких видавалися газети, відсутні статті загального характеру. Частина матеріалів стосувалася конкретних завдань щзодо відновлення та розвитку навчальних закладів та освітнього процесу $і$ підсумків по їх виконанню. Наявний значний сегмент матеріалу критичного характеру, переважно щцодо педагогічних кадрів: їх зовнішнього вигляду, поведінки, методики викладання. Такі замітки були переважно безособовими, а інформація похвального характеру завжди була персональною. Статті щуодо виховного проиесу більше піддавалися впливу пропаганди та розміщувалися на перших ипальтах.

Ключові слова: Друга світова війна, зона військового командування, початкова освіта, окупачія, преса, пропаганда.

Цитування. Оліцький В.О. Висвітлення розвитку початкової освіти у 1941-1943 pp. місцевою пресою Зони військового командування // Сумський історико-архівний журнал. №XXXVI. 2021. С. 15-26. DOI: doi.org/10.21272/shaj.2021.i36.p.15

Друга світова війна залишається актуальним полем досліджень як для світової, так і вітчизняної історичної науки. В Україні після розпаду СРСР відбулося переосмислення багатьох історичних подій, у тому числі пов'язаних із цією війною. Традиційно інтерес істориків спрямовувався переважно на військові дії, політичні процеси, нацистську каральну систему, ідеологію тощо. Із зміщенням акцентів на історію повсякдення, актуалізувалися деякі інші проблеми, серед яких і розвиток освіти в роки окупації. Проте, недостатньо дослідженими залишається значна кількість питань пов'язаних із Другою світовою війною та окупаційним режимом в Україні. Одним із таких є висвітлення місцевою пресою розвитку початкової освіти на окупованих територіях. Традиційно, преса періоду окупації сприймалася виключно як пропагандистський засіб окупаційної адміністрації. Газети розглядали переважно в цьому напрямку, аналізуючи відверто ідеологічні публікації. Фактично, поза увагою дослідників залишалися матеріали повсякденного характеру, зокрема, розвитку освітньої галузі.

Ряд дослідників в тій, чи іншій мірі вивчали дотичні до порушеної теми питання, які допомагають зрозуміти суть освітньої політики, функціонування преси, ступінь пропагандистської інформації в ній тощо. Так окупаційний режим, у тому числі розвиток початкової та середньої освіти у військовій зоні окупації розглядав В. Нестернко (Нестеренко, 2005a; Нестеренко, 2005b). Агітаційно-пропагандистську діяльність, зокрема засобами місцевої преси досліджувала М. Михайлюк (Михайлюк, 2006). Повсякдення українців в період окупації висвітлив В. Шайкан (Шайкан, 2010), 
місцевий аспект проблеми проаналізував А. Скоробагатов (Скоробагатов, 2004). Формування органів окупаційної влади на території військової зони окупації та їх повноваження дослідила С. Власенко (Власенко, 2015). Автор також звертався до даної теми у своїх публікаціях (Оліцький, 2020а; Оліцький, 2020b). Варто відзначити, що більшість дослідників вивчали окупаційну періодику на регіональному рівні (Михайлюк, 2006). Не зважаючи на значну кількість публікацій, порушена проблема не була достатньо дослідженою.

Метою даної статті є розкриття висвітлення місцевою пресою становлення та розвитку початкової освіти у зоні військового командування.

Під час нацистської окупації на території України запроваджувався новий адміністративно-територіальний поділ. Східна Україна (Чернігівська, Харківська, Сумська, Луганська, Донецька області), як території надто близькі до лінії фронту, щоб передавати їх під управління цивільної адміністрації, залишалися під керівництвом військового командування (Плохій, 2018: 344-345; Власенко, 2015: 60). Керівництво цими областями здійснювалося спеціально створеним німецьким військово-адміністративним та військово-економічним апаратом. Комендатури створювали, керували та контролювали місцеві органи влади. Місцеві допоміжні органи влади складали управи, укомплектовані із місцевого населення. Вони формувалися за принципом радянського адміністративно-територіального устрою (Власенко, 2015: 60-61).

Розгалужена система військово-економічних органів управління мала сприяти забезпеченню потреб вермахту та Німеччини. Насамперед мало забезпечуватись безперебійне функціонування економіки регіону та підтримка позитивного ставлення населення до нової влади (Власенко, 2015: 64, 67). Другий аспект реалізовувався переважно через роботу відділів пропаганди. Для посилення їх діяльності використовувалися засоби періодичних видань. Головною метою преси було формування негативного ставлення до радянської влади та виховання лояльності до нової влади, популяризація Німеччини та фюрера як визволителя українського народу (Михайлюк, 2006: 14-15). 3 цією метою публікувалися спеціальні статті у місцевій пресі, у тому числі на історичну тематику. Монополія на пропаганду належала виключно окупаційній адміністрації. Поряд із правдивою інформацією про радянські злочини, часто поширювалася дезінформація (Грицак, 2019: 412).

Структури районних управ охоплювали усі сфери життя району, у тому числі освітню. Для реалізації освітньої політики в структурі районних та міських управ створювалися відділи народної освіти (Власенко, 2015: 61; Нестеренко, 2005b: 80). Відновлення роботи шкіл не стояло на першому місці в роботі німецької адміністрації, вона на сам перед була зацікавлена у відновленні виробництва. Щодо освіти серед військово-політичної верхівки Німеччини та командування у військовій зоні не існувало єдиної позиції (Нестеренко, 2005b: 79-82). Значно більше ця проблема турбувала місцеву владу, розвитком освіти мали опікуватися місцеві адміністрації (Оліцький, 2020b: 158-159). Таким чином, в зоні військового командування вирішення питання становлення і розвитку початкової та середньої освіти виявилося переважно в повноваженнях місцевого населення. Здебільшого цим питанням опікувалися колишні педагоги, зокрема переслідувані радянською владою. Досить часто в дане коло потрапляли патріотично налаштовані діячі. Вони ж зазвичай були і авторами публікацій у місцевій пресі на освітню та педагогічну тематику.

Функціонування місцевих газет відбувалося завдяки підтримці німецької цивільної та місцевої влади, а також органів місцевого самоуправління. 4 листопада 1942 p. 
Куп'янська газета "Новий час" повідомляла про видавництво у “визволених східних областях" 140 часописів, у тому числі 61 україномовного і 18 російськомовних та плани про видання ще 50 газет (140 Часописів, 1942: 2). М. Михайлюк зазначає, що преса, як головний елемент нацистської пропаганди мала певний ефект лише в окремих районах, пов'язуючи це із проблемами доставки газет, малими тиражами (у середньому 1 примірник на 22 особи на території Рейхскомісаріату Україна), контрастом агітаційно-пропагандистських матеріалів із реальністю (Михайлюк, 2006: 15). Варто зазначити, що крім відверто пропагандистських матеріалів, частина публікацій розкриває повсякдення місцевого населення, у тому числі освітнє, релігійне життя і просвіту населення в цілому. Разом із тим, спосіб подання такої інформації, в кінцевому варіанті також містив елементи пропаганди. Матеріал про освіту розміщувався переважно на останніх або передостанніх сторінках газет. У той же час, статті, пов'язані із вихованням розміщувалися на 1-2 сторінці. Таким чином питання виховання стояло на порядок вище за питання навчання, адже воно мало формувати основу відносин між місцевим населенням та новим режимом.

Матеріали місцевої преси зони військового командування щодо розвитку початкової освіти умовно можна поділити на шість груп: висвітлення організації та особливостей навчального процесу; статистичні дані; дидактичні матеріали; характеристика педагогічних кадрів та підвищення їх кваліфікації; представлення нової виховної концепції та висвітлення виховного процесу.

Матеріали щодо відновлення та організації навчального з'являлися уже в перших номерах місцевих видань, що може свідчити про актуальність даної проблеми для місцевої адміністрації. Переважно, подібні замітки, повідомляли про відновлення роботи шкіл, облік педагогічного та учнівського колективів, ремонт пошкоджених шкільних приміщень. Так, у першому номері газети "Відродження" (м. Ромни) 25 листопада 1941 р. надруковано звернення бургомістра П. Андрієвського в якому повідомлялося, що Роменський магістрат за погодженням з окружною військовою комендатурою приступає до підготовки по відкриттю шкіл в місті та окрузі (До всіх, 1941: 2). У першому номері “Бюлетеня Костянтиноградського округового та міського управління” повідомлялося про відновлення, на нових засадах, на території округи 134 шкіл із залученням 684 вчителів, які навчають 13683 учні (Школи Костянтиноградщини, 1942: 2). В публікаціях такого роду крім повідомлення статистичної інформації доводилося до відома читачів про ремонти шкіл, часто із наголосом на їх руйнуванні під час відступу радянських військ. Відзначалися труднощі пов'язані із відновленням пошкоджених шкільних приміщень, зруйнованим обладнанням, підбором педагогів. Матеріали преси свідчать, що ця справа покладалася на місцеві управи, які мали забезпечувати робітниками та матеріалами і контролювати виконану роботу (У.Ф., 1942: 4; Ремонт, 1941: 2; В новій, 1942: 2; Луговий, 1942: 4; Байдик, 1942: 4). Інколи місцева преса публікувала оголошення про відновлення роботи конкретних шкіл, подаючи інформацію про можливість та місце написання заяв для навчання в них (Сумська, 1942: 4). Ідеологічнопропагандистська складова публікацій про відновлення навчання містилася переважно у підкресленні ролі місцевого командування у відродженні шкільного життя, висловленні йому подяки за можливість відновити навчання, забезпечення шкіл необхідними матеріалами (До всіх, 1941: 2; Школи працюють, 1942: 2). Ще одним, важливим, елементом подібних публікацій була демонстрація задоволення та радості населення за можливість продовжувати навчання.

Крім повідомлень у перших номерах місцевих видань, подібні матеріали актуалізувалися напередодні або на початку календарного чи навчального року. Зазвичай, 
у цей період, підбивалися підсумки діяльності навчальних закладів за рік. Подібні замітки містили статистичний матеріал стосовно кількості працюючих шкіл, залучених до їх роботи педагогів та кількості охоплених навчанням учнів. Увага приділялася виконаній відбудовчій роботі шкільної інфраструктури. До відома читачів доводилися плани роботи на наступний період (Дрига, 1942: 1-2; Гнатченко, 1943: 1). В статтях такого характеру аналізувалися проблеми з якими стикалися школи в минулому році. Серед найпоширеніших визначалися недоліки шкільних програм та не забезпечення місцевими управами умов для безперебійної роботи навчальних закладів (Підготовленими, 1942: 3). Але цим не вичерпувалися аналізовані недоліки. Напередодні нового навчального року місцева влада повідомляла населення через газети про відкриття нових шкіл та інших навчальних закладів і можливість щодо їх відвідування (По міських, 1942: 2).

На шпальтах місцевої преси підіймалося питання української мови у новій школі. Примітно, що ця проблема турбувала авторів різних регіонів зони військового командування. Так, “Сумський вісник” акцентував увагу читачів на мовному питанні, стверджуючи, що частина вчителів не вважала за необхідне спілкуватися на перервах та в позанавчальний час із учнями українською мовою (Г.У., 1942: 3). У лютому 1942 р. в газеті "Українське полісся" (Чернігів) вийшла велика стаття "Рідна мова в українській школі” (Рідна, 1942: 2). Невідомий автор докладно проаналізував політику більшовиків щодо української мови в Україні та процес творення нового правопису у 1920-1933 pp. Автор прийшов до висновку, що правопис 1933 р. запроваджувався із метою нівелювання різниці між українським та російським правописами. Аналізуючи таку політику більшовиків, він закликав щоб учителі різних предметів звертали належну увагу на використання літературної української мови, використовували ії не лише на уроках, але і в повсякденні. Дана стаття є показовою тому, що автор не просто закликав до використання української мови, а провів свого роду наукову розвідку проблеми та обгрунтував свою позицію та заклик до педагогів.

Статті, у яких висвітлювалися організація та особливості навчального процесу переважно містили і статистичні відомості. Ці дані розкривали кількість відновлених або працюючих шкіл, в містах або округах, кількість учнів та педагогів. Певні сплески публікації такого роду інформації можна помітити в кінці або на початку навчального чи календарного років. Вони подавалися як у замітках звітного характеру по освіті, так і по соціально-культурній сфері в цілому.

Місцева преса зони військового командування значну увагу приділяла питанню забезпечення освітнього процесу навчальним матеріалом. Дану групу публікацій можна умовно розділити на теоретичні та практичні статті. До теоретичних відносимо переважно матеріали методичного характеру. Одним із найпоширеніших методичних питань, які піймалися на сторінках місцевої преси була заміна радянського навчального матеріалу. Наголошувалося і на ряді проблем, зокрема відсутності шкільних підручників, нової методології тощо. В освітньому процесі заборонялося використовувати радянські та інші підручники, а нових ще не було (Оліцький, 2020а: 61; Байдик, 1942: 4). Газетні публікації інформували читачів про перегляд методичними комісіями підручників. Зокрема "Українське полісся" (Чернігів) повідомляло про створення із числа педагогів предметних комісій для перегляду радянських підручників. Через місяць ця ж газета повідомила про перегляд підручників із хімії, фізики, географії, української мови, посібника для початкового навчання (На нараді, 1941: 2; Підготовка, 1942: 4). "Нова Україна" (Харків) повідомляла про створення міським відділом культури та освіти бригад із “кращих наукових працівників і вчителів” для розробки шкільних програм та 
підручників. Зазначалося про роботу над підручниками з історії України, української мови та літератури (Програми, 1942: 4). Подібні публікації мали інформативний характер, не доводячи до відома читачів суті запроваджуваних змін, лише констатуючи виконання даної роботи.

Місцева влада, в умовах відсутності необхідного навчального матеріалу, за допомогою преси намагалася частково вирішити ситуацію, що склалася. Періодичні видання друкували на своїх шпальтах необхідні для навчання матеріали. В газеті "Відродження" (Ромни) часто публікувалися твори українських та зарубіжних авторів та велася рубрика "На допомогу вчителеві” де подавався необхідний матеріал. Даним методом послугувалася і газета "Українське полісся" (Чернігів) регулярно представляючи рубрику “Сторінка для школярів”. Подібні рубрики були характерними і для інших місцевих видань (Сторінка, 1942: 2; Оліцький, 2020а: 62). Показовою $\epsilon$ стаття окружного інспектора освіти А. Волкова, яка побачила світ напередодні відкриття шкіл в Роменській окрузі, 16 січня 1942 р. Він пропонував в якості навчального матеріалу використовувати усну народну творчість: казки, приказки, прислів'я, пісні, думи. За допомогою даного матеріалу А. Волков закликав вивчати музику, історію, етнографію та естетику, а природознавство опановувати у безпосередній близькості до природи (Волков, 1942а: 1).

Повідомляли місцеві газети і про друк нових підручників, як з метою інформативності населення, так і інформуючи школи засобами періодичної преси про можливість отримання навчальних матеріалів. Зокрема повідомлялося про закупівлю Сумським відділом освіти двох тисяч примірників “Буквара” в Полтавській друкарні (П.Б., 1942а: 4). "Нова Україна" (Харків) 19 липня 1942 р. повідомляла про друк у Харківському кооперативному видавничому товаристві "Українська книжка" "Буквара" i "Вправ 3 української мови” для 7 класу та підготовку іншої літератури. Тут же містився заклик до сільських шкіл Слобожанщини, в разі бажання придбати “Буквара”, зробивши замовлення видавництву через районні управи (ДМ, 1942: 3).

Окреме місце займають публікації що теоретично обгрунтовували існування нової української школи та висвітлювали її основні завдання. Варто відзначити, що подібні статті мали переважно пропагандистський характер та були значними за обсягом. Провідне місце в них займала критика радянської системи освіти. У статтях зазначалося про недостатній рівень знань, які надавала радянська система освіти в цілому. Разом із тим, їх автори справедливо відзначали про русифікацію України за допомогою освіти, перекручування та фальсифікацію української історії в радянській школі (Комашко, 1942b: 4; П.Б., 1942b: 4). Підкреслювалося, що більшовики за допомогою радянської освіти намагалися викорінити українські національні традиції не лише в державі та школі, але й у громадському житті, сім’ї та побуті (Карно, 1942: 3). Автори публікацій постійно писали про відсутність у радянській школі дисципліни та поваги до старших (Сич, 1942: 2; Комашко, 1942а: 3; Бойко, 1942: 1-2). Варто відзначити двоякість подібних публікацій. 3 одного боку, їх автори дійсно переживали за національне відродження та вірили у його можливість за умов нацистської окупації. Тому, в подібних статтях писали про те, що не могли сказати раніше. 3 іншого боку, подібного роду інформація мала сформувати негативне ставлення до радянської влади та забезпечити підтримку новій адміністрації, тим паче, що постійно підкреслювалися роль та місце німецької армії у відродженні національного життя та школи. Основними завданнями шкільної освіти на думку дописувачів була підготовка "здібних до роботи селян, ремісників та фахових робітників” (Відбудова, 1942: 3). В якості прикладу для відродження національної школи в Україні пропонувалася німецька система освіти (Комашко, 1942b: 4). 
Значна увага приділялася формуванню образу нового українського педагога кардинально відмінного від радянського вчителя. Підкреслювалося, що нові вчителі займають почесне та відповідальне місце, на них покладається завдання не лише навчання але і виховання підростаючого покоління (Завдання, 1942: 1). Ю. Бойко у статті "Наше вчительство" зазначав, що основним завданням стоїть виховання українського патріотизму, формування європейського світогляду та поведінки, вмілих працівників у різних галузях. На думку автора, колишні вчителі радянської школи не могли справитися із цими завданнями. Він пропонував підбирати шкільні кадри із числа педагогів, які й за часів УСРР виступали проти більшовицьких ідей (Бойко, 1942: 1-2). У місцевій пресі зустрічається представлення роботи кращих педагогів. Відзначається їх вміння організувати навчальний та виховний процес, забезпечення дисципліни, охайність тощо (Гнатченко, 1943: 1; Кадри шкіл, 1943a: 3; Кадри шкіл, 1943b: 2).

3 метою формування позитивного образу нового вчителя, удосконалення його знань та вмінь місцева преса регулярно повідомляла про вчительські курси та наради. В подібних публікаціях представлялися питання, які обговорювалися, зокрема, становище шкіл, підвищення кваліфікації педагогів, робота над новими підручниками тощо (На вчительських, 1942: 2; Соколенко, 1942: 5; На нараді, 1941:2).

Для висвітлення та формування нового образу шкільного вчителя використовувалося не лише представлення передового досвіду та похвала кращих педагогів але і жорстка критика тих, які на думку місцевої адміністрації не справлялися із своїми завданнями та не відповідали поставленому ідеалу. Варто відзначити, що похвала завжди була спрямована до конкретних вчителів, а критика здебільшого безособовою. Критика педагогічних кадрів яскраво представлена низкою публікацій у газеті "Відродження" (Ромни). Серед проблем які піддавалися найбільшій китиці чільне місце посідало ігнорування вчителями завдань по коригуванню старих підручників або формальне виконання цього виду роботи. Ще однією проблемою, яка піддавалася нищівній критиці був неохайний вигляд педагогів та їхня низька компетентність. Крім того, відзначалися відсутність плану уроку або недбале ставлення до його складання та оформлення, небажання фіксувати в журнал виконану роботу та запізнення на роботу (Кадри шкіл, 1943a: 3; Кадри шкіл, 1943b: 2; Кадри шкіл, 1943c: 4).

В опублікованих газетах та статтях постійно порушувалася тема виховання у відродженій школі (Комашко, 1942а: 3; Ребенок, 1942: 1; Про сучасну, 1942: 2; Шкільний, 1942: 2). Саме публікації даного характеру найбільше піддавалися пропаганді та вимагають особливо критичного ставлення. Бажаючи збільшення авторитету та підтримки місцевого населення в них постійно педалювалися релігійні на національно-патріотичні теми. В публікаціях відзначалася особлива роль трудового виховання та вивчення німецької мови, а один із дописувачів "Сумського вісника" (Суми) взагалі зазначав, що "Мільйони українських дівчат і хлопців разом з молоддю інших націй вже одержують трудові й разом з тим нові моральні якості, працюючи на німецьких підприємствах і ланах. Життя й праця в Німеччині - це краща школа шкіл. Тільки в країні справжнього людського щастя можна одержати правильне виховання" (П.Б., 1942b: 4).

В цілому, нова виховна концепція досить цілісно представлена у статтях інспектора освіти Роменської округи А. Волкова. На шпальтах газети "Відродження" (Ромни) надруковано низку його статей присвячених даному питанню. Ці публікації яскраво ілюструють бачення місцевою владою виховного процесу, його основних принципів та завдань. Постійно наголошувалося, що виховання базуватиметься на нових, відмінних від радянських, принципах та буде аполітичним. До головних завдань відносилися 
національно-патріотичне, морально-релігійне виховання, почуття вдячності німецькому народу та особисто фюреру за звільнення від більшовиків. Підкреслювалася важливість побудови виховної концепції на єдиних принципах для всіх типів шкіл. Автор визначив шість головних принципів нової концепції виховання: національний, аполітичний, трудовий, культурний, патріотичний, релігійний. Крім того, до основних виховних факторів відносилося оточення дитини: сюди автор відносив, як суспільство так і умови проживання. Важливе місце відводилося впливу літератури на виховний процес (Волков, 1941: 1-2; Волков, 1942b: 2; Волков, 1942c: 2). Інші місцеві газети фактично представляли таку ж виховну концепцію. Автор статті в чернігівській газеті “Українське Полісся” Козленко зазначав, що трудове виховання являється єдино правильним. На його думку, діти з 7-8 років діти повинні були відповідати за свої вчинки. Вони мали бути ввічливими, охайними, дисциплінованими (Про сучасну, 1942: 2).

Передбачалося відродження народних традицій у відзначенні свят. Зокрема новорічно-різдвяні свята відзначали із колядками та щедрівками. Разом із тим, пропагувалося формування образу визволителя відносно німецького народу, якому необхідно бути відданими та щиро шанувати (Сисоєв, 1941: 4; Баран-Бутович, 1942: 2).

Преса висвітлювала не лише виховні концепції, але і сам виховний процес. Переважно подібні публікації з'являлися в період релігійних або державних свят. При описанні народних свят відзначалося відродження народних традицій. Крім відродження традиційних релігійних святкувань характерним для всіх регіонів зони військового командування було відзначення Шевченківських днів (Шкільний, 1942: 2). В публікаціях про державні свята відзначалася дисциплінованість учнів, їхня вдячність німецькому народу та А. Гітлеру. Одними із незмінних атрибутів святкувань було панування української мови, присутність церкви, портретів Т. Шевченка та А. Гітлера. Таким чином преса намагалася піднести образ А. Гітлера за рахунок народного шанування Т. Шевченка, ставлячи їх в один ряд.

На тлі значної кількості газетних публікацій присвячених новій українській школі та iii завданням і успіхам, варто відзначити часте порушення питання відвідуваності учнями школи. Наявність значної кількості подібного матеріалу свідчить про те, що дане питання було актуальним для місцевої влади, існувала проблема із відвідуванням школи. Батькам повідомлялося, що всі діти шкільного віку неодмінно повинні ходити до школи, місцеві управи закликалися до сприяння цьому. Низька відвідуваність вважалася однією із головних проблем. Публічно відповідальність за це покладалася на колишню радянську школу, а не пов'язувалася із негативним сприйняттям населенням нового режиму (Сич, 1942: 2; Байдик, 1942: 4; До уваги, 1942: 2).

Отже, функціонування місцевих газет відбувалося завдяки підтримці окупаційної влади, преса розглядалася як один із елементів пропаганди. Це впливало на інформаційне наповнення часописів та спосіб подачі інформації. У зв'язку із рядом причин, у тому числі малими тиражами та проблемами доставки, пропаганда засобами місцевої періодики мала певний ефект лише в окремих районах. Ряд газетних публікацій розкривали особливості повсякденного життя на окупованій території, у тому числі питання відновлення та розвитку початкової освіти. Такі матеріали умовно можна поділити на кілька груп: висвітлення організації та особливостей навчального процесу; статистичні дані; дидактичні матеріали; характеристика педагогічних кадрів та підвищення їх кваліфікації. Вони найменше піддавалися пропаганді, їх авторами були переважно члени місцевих управ. Публікації щодо виховного процесу, навпаки, більше піддавалися впливу пропаганди. Не зважаючи на це, матеріали місцевої преси є важливим джерелом вивчення 
відновлення та розвитку початкової освіти в зоні військового командування. В перспективі необхідно приділити увагу з'ясуванню впливу подібних публікацій на настрої населення, а відповідно їх ефективність. Порівняння інформації періодичної преси та архівних матеріалів дасть змогу з'ясувати ступінь достовірності поширюваних в газетах матеріалів.

\section{Література:}

140 Часописів, 1942 - 140 Часописів у визволених областях // Новий час (Куп'янськ). 1942. 4 листопада. № 5. С. 2.

Байдик, 1942 - Байдик П. Школи відповідальна ділянка роботи сільських управ // Сумський вісник. 1942. 11 листопада. № 135. С. 4.

Баран-Бутович, 1942 - Баран-Бутович С. Рік відбудовної роботи в галузі освіти та культури // Українське полісся (Чернігів). 1942.9 вересня. № 101. С. 2.

C. $1-2$

Бойко, 1942 - Бойко Ю. Наше вчительство // Нова Україна (Харків). 1942. 23 серпня. № 187.

В новій, 1942 - В новій школі // Українське полісся (Чернігів). 1942. 25 січня. № 11. С. 2.

Відбудову, 1942 - Відбудову нової української школи забезпечено // Нова Україна (Харків).

1942. 4 жовтня. № 223. С. 3.

Власенко, 2015 - Власенко C. Органи влади на території військової зони України в період нацистської окупації: організація, підбір кадрів, функціонування (1941-1943рр.) // Сіверянський літопис. 2015. №. 2. С. 60-69.

Волков, 1941 - Волков А.С. Наші завдання у вихованні // Відродження (Ромни). 1941. 16 грудня. № 7. С. 1-2.

Волков, 1942a - Волков А.Б. Багатющі джерела виховного й освітнього матеріалу // Відродження (Ромни). 1942. 16 січня. № 5. С. 1.

Волков, 1942b-Волков А.С. Про виховання // Відродження (Ромни). 1942. 11 грудня. № 93. С. 2. Волков, 1942c - Волков А.С. Про виховання // Відродження (Ромни). 1942. 8 грудня. № 92. С. 2. № 101. С. 3 .

Г.У., 1942 - Г.У. Недоліки минулого навчального року // Сумський вісник. 1942. 23 серпня.

Гнатченко, 1943 - Гнатченко. Н. Впевнено вступаєм в 1943 рік // Новий час (Куп'янськ). 1943. 1 січня. № 1. С. 1 .

Грицак, 2019 - Грицак Я. Нарис історії України. Формування модерної нації XIX-XX століття.

К.: Yakaboo Publishing, 2019. 656 c.

№ 158. С. 3 .

ДМ., 1942 - ДМ. С-ВЕЙ. Шкільне життя Харкова // Нова Україна (Харків). 1942.19 липня.

До всіх, 1941 - До всіх уповноважених і Магістрату, директорів шкіл та сільських старост

Роменської округи // Відродження (Ромни). 1941. 25 листопада. № 1. С. 2.

До уваги, 1942 - До уваги батьків // Українське полісся (Чернігів). 1942. 7 жовтня. № 112. С. 2.

№ 161. С. $1-2$.

Завдання, 1942 - Завдання українського вчительства // Українське полісся (Чернігів). 1942.

9 січня. № 4. С. 1 .

№ 4. С. 3 .

Кадри шкіл, 1943a - Кадри шкіл Роменської округи // Відродження (Ромни). 1943. 15 січня.

№ 5. С. 2 .

Кадри шкіл, 1943b - Кадри шкіл Роменської округи // Відродження (Ромни). 1943. 19 січня.

№ 6. С. 4 .

Кадри шкіл, 1943c - Кадри шкіл Роменської округи // Відродження (Ромни). 1943. 20 січня.

Карно, 1942 - Карно А. Московський імперіалізм і освіта на Україні // Нова Україна (Харків).

1942. 6 грудня. № 277. С. 3.

Комашко, 1942а - Комашко Ю. Думки про виховання молоді // Нова Україна (Харків). 1942.

7 березня. № 46. С. 3 .

Комашко, 1942b - Комашко Ю. Думки про українську школу // Нова Україна (Харків). 1942.

17 січня. № 6. С. 4.

Луговий, 1942 - Луговий Г. Шкільне будівництво у Ново-Водолазькому районі // Нова Україна (Харків). 1942. 18 лютого. № 31. С. 4.

Михайлюк, 2006 - Михайлюк М. Агітаційно-пропагандистська діяльність органів німецької окупаційної влади серед населення України (1941-1944рр.): автореф. дис. ... канд. іст. наук: 07.00.01. Київ, 2006, 22 с.

На вчительських, 1942 - На вчительських курсах // Нова Україна (Харків). 1942.7 серпня. № 174 . С. 2.

На нараді, 1941 - На нараді вчителів // Українське полісся (Чернігів). 1941. 5 грудня. № 12. С. 2. 
Нестеренко, 2005a - Нестеренко В. Окупаційний режим у військовій зоні України в 19411943 pp. (адміністративний, економічний та соціокультурний аспекти): дис. канд. іст. наук: 07.00.01. Київ, 2005.307 с.

Нестеренко, 2005b - Нестеренко В. Політика в галузі початкової і середньої освіти у військовій зоні України у 1941-1943 рр. // Сумська старовина. 2005. № XV. С. 79-91.

Оліцький, 2020а - Оліцький В. Висвітлення розвитку початкової освіти у 1941-1943 рр. місцевою пресою (на прикладі газети “Відродження” м. Ромни) // Сумська старовина. 2020. № LVI. C. 58-65.

Оліцький, 2020b - Оліцький В. Висвітлення становлення початкової освіти на Роменщині у матеріалах газети “Відродження” (1942-1942рр.) // Формування громадянської культури в Новій українській школі: традиційні та інноваційні практики: збірник матеріалів конференції. (м. Суми, 1819 червня 2020 р.). Суми, 2020. С. 157-161.

П.Б., 1942а - П.Б. Новий буквар // Сумський вісник. 1942. 20 листопада. № 139. С. 4.

П.Б., 1942b - П.Б. Про виховання молоді // Сумський вісник. 1942. 12 липня. № 83. С. 4.

Підготовка, 1942 - Підготовка до навчання в школах // Українське полісся (Чернігів). 1942. 1 січня. № 1. С. 4.

Підготовленими, 1942 - Підготовленими зустрінемо учбовий рік! // Сумський вісник. 1942. 5 серпня. № 93. С. 3.

Плохій, 2018 - Плохій C. Брама Європи / пер. з англ. Р. Клочко. Харків: Книжковий Клуб “Клуб Сімейного Дозвілля”, 2018. 496 с.

По міських, 1942 - По міських школах // Українське полісся (Чернігів). 1942. 30 серпня. № 97. C. 2 .

Про сучасну, 1942 - Про сучасну українську школу // Українське полісся (Чернігів). 1942.

28 січня. № 12 . С. 2.

№ 5. C. 4 .

Програми, 1942 - Програми і підручники для шкіл // Нова Україна (Харків). 1942. 16 січня.

Ребенок, 1942 - Ребенок Г. До праці, українське вчительство! // Українське полісся (Чернігів). 1942. 21 січня. № 9. С. 1.

Ремонт, 1941 - Ремонт шкіл // Українське полісся (Чернігів). 1941. 19 листопада. № 6. С. 2.

Рідна, 1942 - Рідна мова в українській школі // Українське полісся (Чернігів). 1942. 1 лютого.

№ 13. C. 2 .

Сисоєв, 1941 - Сисоєв М. Українське вчительство Роменщини - до роботи! // Відродження.

1941. 5 грудня. № 4. С. 4.

Сич, 1942 - Сич. До батьків! // Бюлетень Костянтиноградського округового та міського управління. 1942. 21 квітня. № 15. С. 2.

Скоробогатов, 2004 - Скоробогатов А. Харків у часи німецької окупації (1941-1943).

Харків: Прапор, 2004. 368 с.

Соколенко, 1942 - Соколенко Д. Нарада вчителів // Бюлетень Костянтиноградського округового та міського управління. 1942. 3 березня. № 1. С. 5.

Сторінка, 1942 - Сторінка для школярів // Українське полісся (Чернігів). 1942. 1 березня.

№ 25. C. 2 .

Сумська, 1942 - Сумська початкова школа № 3 // Сумський вісник. 1942. 21 серпня. № 100. С. 4. № 64. С. 4 .

У.Ф., 1942 - У.Ф. Школа у Мокро-Ракитному // Нова Україна (Харків). 1942. 28 березня.

Шайкан, 2010 - Шайкан В. Повсякдення українців у роки німецької окупації 1941-1944. Київ, 2010.80 с.

Шкільний, 1942 - Шкільний П. По школах району // Українське полісся (Чернігів). 1942. 27 лютого. № 24. С. 2.

Школи Костянтиноградщини, 1942 - Школи Костянтиноградщини // Бюлетень Костянтиноградського округового та міського управління. 1942. 3 березня. № 1. С. $2-3$.

Школи працюють, 1942 - Школи працюють // Українське полісся (Чернігів). 1942. 18 січня. № 8. С. 2.

\section{References:}

140, 1942 - 140 Chasopysiv u vyzvolenykh oblastiakh [140 magazines in the liberated areas] // Novyi chas (Kupiansk). 1942. 4 lystopada. № 5. S. 2. [in Ukrainian].

Baidyk, 1942 - Baidyk P. Shkoly vidpovidalna dilianka roboty silskykh uprav [Schools are a responsible area of work of village councils] // Sumskyi visnyk. 1942. 11 lystopada. № 135. S. 4. [in Ukrainian].

Baran-Butovych, 1942 - Baran-Butovych $S$. Rik vidbudovnoi roboty v haluzi osvity ta kultury [Year of reconstruction work in the field of education and culture] // Ukrainske polissia (Chernihiv). 1942. 9 veresnia. № 101. S. 2. [in Ukrainian].

Boiko, 1942 - Boiko Yu. Nashe vchytelstvo [Our teaching] // Nova Ukraina (Kharkiv). 1942. 23 serpnia. № 187. S. 1-2. [in Ukrainian].

V novii, 1942 - V novii shkoli [In the new school] // Ukrainske polissia (Chernihiv). 1942.25 sichnia. № 11. S. 2. [in Ukrainian]. 
Vidbudovu, 1942 - Vidbudovu novoi ukrainskoi shkoly zabezpecheno [Reconstruction of the new Ukrainian school is provided] // Nova Ukraina (Kharkiv). 1942. 4 zhovtnia. № 223. S. 3. [in Ukrainian].

Vlasenko, 2015 - Vlasenko $S$. Orhany vlady na terytorii viiskovoi zony Ukrainy v period natsystskoi okupatsii: orhanizatsiia, pidbir kadriv, funktsionuvannia (1941-1943 rr.) [Authorities in the military zone of Ukraine during the Nazi occupation: organization, recruitment, functioning (1941-1943)] // Siverianskyi litopys. 2015. №. 2. S. 60-69. [in Ukrainian].

Volkov, 1941 - Volkov A.S. Nashi zavdannia u vykhovanni [Our tasks in education]// Vidrodzhennia (Romny). 1941. 16 hrudnia. № 7. S. 1-2. [in Ukrainian].

Volkov, 1942a - Volkov A.B. Bahatiushchi dzherela vykhovnoho y osvitnoho materialu [Rich sources of educational material] // Vidrodzhennia (Romny). 1942. 16 sichnia. № 5. S. 1. [in Ukrainian]. Volkov, 1942b - Volkov A.S. Pro vykhovannia [About education] // Vidrodzhennia (Romny). 1942. 11 hrudnia. № 93. S. 2. [in Ukrainian].

Volkov, 1942c - Volkov A.S. Pro vykhovannia [About education] // Vidrodzhennia (Romny). 1942. 8 hrudnia. № 92. S. 2. [in Ukrainian].

H.U., $1942-H . U$. Nedoliky mynuloho navchalnoho roku [Disadvantages of the last school year] // Sumskyi visnyk. 1942. 23 serpnia. № 101. S. 3. [in Ukrainian].

Hnatchenko, 1943 - Hnatchenko. $N$. Vpevneno vstupaiem v 1943 rik [We are confidently entering 1943] // Novyi chas (Kupiansk). 1943. 1 sichnia. № 1. S. 1. [in Ukrainian].

Hrytsak, 2019 - Hrytsak Ya. Narys istorii Ukrainy. Formuvannia modernoi natsii XIX-XX stolittia [Essay on the history of Ukraine. Formation of a modern nation of the XIX-XX centuries]. K.: Yakaboo Publishing, 2019.656 s. [in Ukrainian].

DM., 1942 - DM. S-VEI. Shkilne zhyttia Kharkova [School life in Kharkiv] // Nova Ukraina (Kharkiv).

1942. 19 lypnia. № 158. S. 3. [in Ukrainian].

Do vsikh, 1941 - Do vsikh upovnovazhenykh i Mahistratu, dyrektoriv shkil ta silskykh starost Romenskoi okruhy [To all commissioners and the Magistrate, school principals and village elders of the Romensky district] // Vidrodzhennia (Romny). 1941. 25 lystopada. № 1. S. 2. [in Ukrainian].

Do uvahy, 1942 - Do uvahy batkiv [To the attention of parents] // Ukrainske polissia (Chernihiv). 1942. 7 zhovtnia. № 112. S. 2. [in Ukrainian].

Dryha, 1942 - Dryha P. Na porozi navchalnoho roku [On the threshold of the school year] // Nova Ukraina (Kharkiv). 1942. 23 lypnia. № 161. S. 1-2. [in Ukrainian].

Zavdannia, 1942 - Zavdannia ukrainskoho vchytelstva [Tasks of Ukrainian teachers] // Ukrainske polissia (Chernihiv). 1942. 9 sichnia. № 4. S. 1. [in Ukrainian].

Kadry shkil, 1943a - Kadry shkil Romenskoi okruhy [Staff of schools of the Romensky district] // Vidrodzhennia (Romny). 1943. 15 sichnia. № 4. S. 3. [in Ukrainian].

Kadry shkil, 1943b - Kadry shkil Romenskoi okruhy [Staff of schools of the Romensky district] // Vidrodzhennia (Romny). 1943. 19 sichnia. № 5. S. 2. [in Ukrainian].

Kadry shkil, 1943c - Kadry shkil Romenskoi okruhy [Staff of schools of the Romensky district] // Vidrodzhennia (Romny). 1943. 20 sichnia. № 6. S. 4. [in Ukrainian].

Karno, 1942 - Karno A. Moskovskyi imperializm i osvita na Ukraini [Moscow imperialism and education in Ukraine] // Nova Ukraina (Kharkiv). 1942. 6 hrudnia. № 277. S. 3. [in Ukrainian].

Komashko, 1942a - Komashko Yu. Dumky pro vykhovannia molodi [Thoughts about educating young people] // Nova Ukraina (Kharkiv). 1942. 7 bereznia. № 46. S. 3. [in Ukrainian].

Komashko, 1942b - Komashko Yu. Dumky pro ukrainsku shkolu [Thoughts about the Ukrainian school] // Nova Ukraina (Kharkiv). 1942. 17 sichnia. № 6. S. 4. [in Ukrainian].

Luhovyi, 1942 - Luhovyi H. Shkilne budivnytstvo u Novo-Vodolazkomu raioni [School construction in Novo-Vodolazhsky district] // Nova Ukraina (Kharkiv). 1942. 18 liutoho. № 31. S. 4. [in Ukrainian].

Mykhailiuk, 2006 - Mykhailiuk M. Ahitatsiino-propahandystska diialnist orhaniv nimetskoi okupatsiinoi vlady sered naselennia Ukrainy (1941-1944 rr.) [Campaigning and propaganda activities of the German occupation authorities among the population of Ukraine (1941-1944)]: avtoreferat dys. kand. ist. nauk: 07.00.01. Kyiv, 2006, 22 s. [in Ukrainian].

Na vchytelskykh, 1942 - Na vchytelskykh kursakh [In teacher training courses] // Nova Ukraina (Kharkiv). 1942. 7 serpnia. № 174. S. 2. [in Ukrainian].

Na naradi, 1941 - Na naradi vchyteliv [At the teachers' meeting] // Ukrainske polissia (Chernihiv). 1941. 5 hrudnia. № 12 . S. 2 .

Nesterenko, 2005a - Nesterenko $V$. Okupatsiinyi rezhym u viiskovii zoni Ukrainy v 1941-1943 rr. (administratyvnyi, ekonomichnyi ta sotsiokulturnyi aspekty) [Occupation regime in the military zone of Ukraine in 1941-1943 (administrative, economic and socio-cultural aspects)]: dys. kand. ist. nauk: 07.00.01. Kyiv, 2005. 307 s. [in Ukrainian].

Nesterenko, 2005b - Nesterenko $V$. Polityka v haluzi pochatkovoi i serednoi osvity u viiskovii zoni Ukrainy u 1941-1943 rr. [Policy in the field of primary and secondary education in the military zone of Ukraine in 1941-1943.] // Sumska starovyna. 2005. № XV. S. 79-91. [in Ukrainian].

Olitskyi, 2020a - Olitskyi $V$. Vysvitlennia rozvytku pochatkovoi osvity u 1941-1943 rr. mistsevoiu presoiu (na prykladi hazety "Vidrodzhennia" m. Romny) [Coverage of the development of primary education 
in 1941-1943 by the local press (on the example of the newspaper "Vidrodzhennia" in Romny)] // Sumska starovyna. 2020. № LVI. S. 58-65. [in Ukrainian].

Olitskyi, 2020b - Olitskyi $V$. Vysvitlennia stanovlennia pochatkovoi osvity na Romenshchyni u materialakh hazety "Vidrodzhennia" (1942-1942 rr.) [Coverage of the formation of primary education in the Romny region in the materials of the newspaper "Vidrodzhennia" (1942-1942)] // Formuvannia hromadianskoi kultury v Novii ukrainskii shkoli: tradytsiini ta innovatsiini praktyky: zbirnyk materialiv konferentsii. (m. Sumy, 18-19 chervnia 2020 r.). Sumy, 2020. S. 157-161. [in Ukrainian]. Ukrainian]. P.B., 1942a - P.B. Novyi bukvar [New primer] // Sumskyi visnyk. 1942. 20 lystopada. № 139. S. 4. [in P.B., 1942b - P.B. Pro vykhovannia molodi [About education of youth] // Sumskyi visnyk. 1942. 12 lypnia. № 83. S. 4. [in Ukrainian].

Pidhotovka, 1942 - Pidhotovka do navchannia v shkolakh [Preparation for schooling] // Ukrainske polissia (Chernihiv). 1942. 1 sichnia. № 1. S. 4. [in Ukrainian].

Pidhotovlenymy, 1942 - Pidhotovlenymy zustrinemo uchbovyi rik! [We will meet the school year prepared!] // Sumskyi visnyk. 1942. 5 serpnia. № 93. S. 3. [in Ukrainian].

Plokhii, 2018 - Plokhii S. Brama Yevropy [Gate of Europe] / per. z anhl. R. Klochko. Kharkiv: Knyzhkovyi Klub "Klub Simeinoho Dozvillia”, 2018. 496 s. [in Ukrainian].

Po miskykh, 1942 - Po miskykh shkolakh [By city schools] // Ukrainske polissia (Chernihiv). 1942. 30 serpnia. № 97. S. 2. [in Ukrainian].

Pro suchasnu, 1942 - Pro suchasnu ukrainsku shkolu [About the modern Ukrainian school] // Ukrainske polissia (Chernihiv). 1942. 28 sichnia. № 12. S. 2. [in Ukrainian].

Prohramy, 1942 - Prohramy i pidruchnyky dlia shkil [Programs and textbooks for schools] // Nova Ukraina (Kharkiv). 1942. 16 sichnia. № 5. S. 4. [in Ukrainian].

Rebenok, 1942 - Rebenok H. Do pratsi, ukrainske vchytelstvo! [To work, Ukrainian teachers!] // Ukrainske polissia (Chernihiv). 1942. 21 sichnia. № 9. S. 1. [in Ukrainian].

Remont, 1941 - Remont shkil [Repair of schools] // Ukrainske polissia (Chernihiv). 1941. 19 lystopada. № 6. S. 2. [in Ukrainian].

Ridna, 1942 - Ridna mova v ukrainskii shkoli [Native language in the Ukrainian school] // Ukrainske polissia (Chernihiv). 1942. 1 liutoho. № 13. S. 2. [in Ukrainian].

Sysoiev, 1941 - Sysoiev $M$. Ukrainske vchytelstvo Romenshchyny - do roboty! [Ukrainian teachers of Romenshchyna - to work!] // Vidrodzhennia. 1941. 5 hrudnia. № 4. S. 4. [in Ukrainian].

Sych, 1942 - Sych. Do batkiv! [To the parents!] // Biuleten Kostiantynohradskoho okruhovoho ta miskoho upravlinnia. 1942. 21 kvitnia. № 15. S. 2. [in Ukrainian].

Skorobohatov, 2004 - Skorobohatov A. Kharkiv u chasy nimetskoi okupatsii (1941-1943) [Kharkiv during the German occupation (1941-1943)]. Kharkiv: Prapor, 2004. 368 s. [in Ukrainian].

Sokolenko, 1942 - Sokolenko D. Narada vchyteliv [Teachers' meeting] // Biuleten Kostiantynohradskoho okruhovoho ta miskoho upravlinnia. 1942. 3 bereznia. № 1. S. 5. [in Ukrainian].

Storinka, 1942 - Storinka dlia shkoliariv [Page for schoolchildren] // Ukrainske polissia (Chernihiv).

1942. 1 bereznia. № 25. S. 2. [in Ukrainian].

Sumska, 1942 - Sumska pochatkova shkola № 3 [Sumy primary school № 3] // Sumskyi visnyk. 1942. 21 serpnia. № 100. S. 4. [in Ukrainian].

U.F., 1942 - U.F. Shkola u Mokro-Rakytnomu [School in Mokro-Rokytne] // Nova Ukraina (Kharkiv). 1942. 28 bereznia. № 64. S. 4. [in Ukrainian].

Shaikan, 2010 - Shaikan V. Povsiakdennia ukraintsiv u roky nimetskoi okupatsii 1941-1944 [Everyday life of Ukrainians during the years of German occupation 1941-1944]. Kyiv, 2010. 80 s. [in Ukrainian]. Shkilnyi, 1942 - Shkilnyi P. Po shkolakh raionu [By district schools] // Ukrainske polissia (Chernihiv). 1942. 27 liutoho. № 24. S. 2. [in Ukrainian].

Shkoly Kostiantynohradshchyny, 1942 - Shkoly Kostiantynohradshchyny [Schools of Constantinople] // Biuleten Kostiantynohradskoho okruhovoho ta miskoho upravlinnia. 1942. 3 bereznia. № 1. S. 2-3. [in Ukrainian].

Shkoly pratsiuiut, 1942 - Shkoly pratsiuiut [Schools are working] // Ukrainske polissia (Chernihiv). 1942. 18 sichnia. № 8. S. 2. [in Ukrainian]. 